\title{
Prevalence of HBsAg Among Prospective Blood Donors and Pregnant Women in Kebbi State, Nigeria
}

\author{
${ }^{2}$ A. Yakubu , 1D.M. Sahabi, ${ }^{1}$ A. Umar A., ${ }^{1 Y}$. Saidu and *3 U.F. Magaji \\ ${ }^{1}$ Department of Biochemistry, Usmanu Danfodiyo University Sokoto, P.M.B. 2346, Sokoto, Nigeria \\ ${ }^{2}$ Department of Internal Medicine, Usmanu Danfodiyo University Teaching Hospital Sokoto, Nigeria \\ ${ }^{3}$ Department of Biochemistry and Molecular Biology, Federal University Birnin Kebbi, P.M.B. 1157, Kebbi State, Nigeria \\ [ ${ }^{\star}$ Corresponding author: umarumagaji97@gmail.com; : : +2348067025337]
}

\begin{abstract}
This study was aimed at determining the prevalence of Hepatitis B surface antigen ( $\mathrm{HBs} A \mathrm{~g})$ among prospective blood donors and pregnant women in Kebbi State, Nigeria. Three hundred and sixty one (361) apparently healthy prospective blood donors were recruited and screened for HBsAg using HBsAg rapid test kit. Those that tested positive for HBsAg (16.6\%) were further assessed for liver function. The prevalence by gender was $23.4 \%$ and $13.1 \%$ for male and female subjects respectively. Prevalence by the three senatorial zones of the state is in the order Kebbi South (21.8\%) > Kebbi North (15.1\%) > Kebbi Central (13.6\%). Subjects within the age group 26-30 years had the highest HBsAg prevalence of $20.9 \%$ compared to the other age groups. Single males have higher prevalence (26.1\%) of HBV infection than their married counterparts (16.7\%). Local government workers had highest prevalence (29.2\%) followed by self-employed (27.6\%) and then state government employees (14.3\%). In females, occupational exposure (healthcare worker) and polygamy are risk factors with highest prevalence of $40.0 \%$ and $23.2 \%$ respectively. The levels of serum liver enzymes and bilirubin were significantly higher $(p<0.05)$ in HBsAg positive subjects compared to the HBsAg negative subjects. The reverse was, however, the case for albumin. Our result suggests that Kebbi State is one of the HBsAg hyper-endemic areas in Nigeria.

Keywords: Hepatitis B, Prevalence, Liver function test, Kebbi State.
\end{abstract}

\section{INTRODUCTION}

Hepatitis $B$, also known as serum hepatitis is a disease of the liver caused by a double stranded DNA virus of the family Hepadnaviridae, which is reported to be the main aetiological factor in over $75 \%$ of chronic liver diseases worldwide (Ryan and Ray, 2004; Pungpapong et al., 2007; Oladele et al., 2013). Hepatitis B virus (HBV) is resistant to inactivation by heat and is highly infectious; it is 50-100 times more infectious than HIV and 10 times more infectious than hepatitis $\mathrm{C}$. The virus is detected in virtually all body fluids (i.e. blood, saliva, semen, vaginal secretion, menstrual blood and to lesser extent in perspiration, breast milk, tears and urine) of infected individuals (Lavanchy, 2004; Elgouhari et al., 2008).

HBV infection is among the leading public health burdens especially in developing countries (Samuel et al., 2004; Elgouhari et al., 2008). In high prevalence areas, the most common routes of HBV transmission are perinatal and horizontal transmissions (Gitlin, 1997; Hollinger and Liang, 2001). Also, heterosexual practices, unprotected sex, injections, blood transfusion as well as sharing of sharp objects are among possible routes of transmission (Harry et al., 1994; Seeger and Mason, 2000; Oladele et al., 2013).
An estimated $5 \%$ of the global population is infected with $\mathrm{HBV}$, with more than 350 million people as chronic carriers and over 1 million deaths annually (WHO, 1998; Drosten et al., 2004; Sharma et al., 2005; Liu and Hou, 2006; Ziraba et al., 2010; Eke et al., 2011). The prevalence of HBV varies significantly over the globe; low prevalence of $2 \%$ is reported in developed countries, while developing countries have prevalence of $>8.0 \%$ (Lule, 1997). Sub-Saharan Africa is HBV hyper-endemic, with $8-20 \%$ prevalence. Approximately 50 million people are chronic carriers (Drosten et al., 2004; Heathcote, 2008; Majori et al., 2008; Ziraba et al., 2010).

HBV infection is a serious health challenge in Nigeria. Seventy five (75) percent of the total population is exposed to the infection at one time of their life or the other, with an estimated 12\% prevalence of chronic carriers (Alao et al., 2009; Oladele et al., 2013). Due to the infectious and asymptomatic nature of HBV infection, poor health care facilities and inadequate monitoring of HBV infection, controlling the spread of HBV infection remain a major challenge (Okoye and Samba, 2006).

The prevalence of HBV infection is disproportionate within the Nigerian population (Alao et al., 2009). Bello et al., (2013) reported $14.0 \%$ prevalence among patients visiting Sokoto Specialist Hospital, Sokoto. More so, a 
prevalence of $7.9 \%$ and $7.6 \%$ were reported for pregnant and nonpregnant women respectively attending Aminu Kano Teaching Hospital, Kano (Yakasai et al., 2012). Study of ante-natal patients attending various clinics in Gwagwalada metropolis of Abuja revealed 9.5\% prevalence (Agarry and Lekwot, 2010). Forbi et al. (2008) reported a prevalence of $17.1 \%$ among female sex workers in Nasarawa State. A prevalence of $9.0 \%$ in Mubi and $8.2 \%$ among pregnant women in Yola of Adamawa State was reported by Okoye and Samba, (2006) and Olokoba et al. (2011) respectively. In Jos, Plateau State, a prevalence of $20.8 \%$ was reported by Adekeye et al., (2013). Angyo et al., (1995) reported $19.5 \%$ prevalence among children attending Jos University Teaching Hospital, Plateau State.

This study was aimed at determining the prevalence of HBV among prospective blood donors and pregnant women in Kebbi State and assessment of liver function of the HBV infected subjects.

\section{MATERIALS AND METHODS \\ Study Area and Population}

Three hundred and sixty one (361) apparently healthy blood donors and pregnant women within the age of 1835 years, attending Argungu General Hospital, Sir Yahaya Specialist Hospital Birnin Kebbi and Martha Bamaiyi General Hospital Zuru all in Kebbi State, Nigeria, who willingly consented to participate in the study, were screened for HBV infection between the months of January to December, 2012. Subjects with established cases of liver disease and/or HIV infection where excluded from the study. Questionnaire was administered to obtain additional information/ history of each participant.

\section{Ethical Approval}

This research was approved by the ethical committee of Kebbi State Ministry of Health, Birnin Kebbi, Kebbi State, Nigeria.

\section{Sample Collection and Preparation}

Five milliliters of venous blood were collected from each participant using sterile syringe and transferred into plain specimen bottles. The blood was allowed to clot for 30 minutes, and then centrifuged at $2500 \mathrm{rpm}$ for five minutes. The serum obtained was used for the analyses.

\section{HBV Analysis/ Test}

Serum samples were tested for the presence of HBV infection using HBsAg rapid test kit (ACON, USA) which is based on the principle of antigen-antibody reaction.
The test and interpretation of results were carried out based on the manufacturer's specifications and guidelines.

\section{Liver Function Test and Prothrombin Time Estimation}

HBsAg positive subjects were further screened for liver function parameters. Standard methods were used to determine Total Protein (Weichselbaum, 1946), Albumin (Doumas et al., 1971), Total Bilirubin (Doumas et al., 1973), Direct Bilirubin (Doumas et al., 1973), Aspartate aminotransferase (AST) (Reitman and Frankel, 1957), Alanine aminotransferase (ALT) (Reitman and Frankel, 1957), Alkaline Phosphatase (ALP) (Tietz et al., 1983) and Prothrombin Time (Quick, 1935). HBsAg negative subjects served as controls.

\section{Data Analysis}

Data obtained for liver function parameters were expressed as Mean \pm Standard deviation. All the parameters were analysed statistically at $P<0.05$ by oneway analysis of variance (ANOVA) using GraphPad InStat Software (Version 3.05, San Diego, USA).

\section{RESULT AND DISCUSSION}

The prevalence of HBV infection among prospective blood donors and pregnant women in Kebbi State is presented in Table 1.

Table 1: Prevalence of HBsAg in Kebbi State, Nigeria

\begin{tabular}{lccc}
\hline Gender & $\begin{array}{c}\text { No. of } \\
\text { Screened } \\
\text { Subjects }\end{array}$ & $\begin{array}{l}\text { No. of } \\
\text { HBsAg +ve } \\
\text { Subjects }\end{array}$ & $\begin{array}{c}\text { Prevalence } \\
(\%)\end{array}$ \\
\hline Male & 124 & 29 & 23.4 \\
Female & 237 & 31 & 13.1 \\
Total & 361 & 60 & 16.6 \\
\hline
\end{tabular}

The result reveal that Kebbi State has a high prevalence of HBV $(16.6 \%)$, thus, is hyper-endemic. Males exhibited a higher prevalence of $23.4 \%$ as compared to females with 13.1\%. This finding agrees with earlier reports (Oladele et al., 2013) classifying Nigeria as a HBV endemic region.

Based on senatorial district, Kebbi South has the highest prevalence rate $(21.8 \%)$, followed by Kebbi North (15.1\%), while Kebbi Central has the least prevalence (13.6\%) (Table 2). Higher prevalence in Kebbi South and Kebbi North as compared to Kebbi Central may be attributed to poor awareness and counseling as well as difficulty in accessing healthcare facilities. Occupational 
and mechanical transfers are also possible means of transmission in these areas, which is due to low socioeconomic status and remoteness of the zones.

The prevalence of HBV among age groups in Kebbi State is shown in Table 3. A high prevalence of $20.9 \%$ was observed among 26-30 years age group. This is presumed to be due to the more sexually active life of youth at the stated age (Khan et al., 2011). Also, optimal social interactions and occupational interest (especially in self-employed) are observed within the stated age, thus, may be additional causes of exposure (Khan et al., 2011).

The prevalence of HBV by risk factors for males and females in Kebbi State are presented in Tables 4 and 5 respectively. Though, all the male subjects denied casual sex life style, a higher prevalence of HBV (26.1\%) was observed in single subjects when compared to married subjects (16.7\%).

Also, male subjects having a history of sharing sharp objects had an extremely high prevalence of HBV infection (80.6\%). This concurs with reports of Khan et al. (2011) which suggests that sharing of sharp objects or needles is a possible route of HBV transmission due to its high infectious potential (Samuel et al., 2004).

For female participants, polygamy (2nd marriage) and occupational exposure (healthcare workers) are risk factors with highest prevalence $(23.2 \%$ and $40.0 \%$ respectively). Our findings agree with the report of Olubiyide et al. (1997), which suggest that occupational exposure can be a major route of HBV transmission.

Liver Function Parameters and Prothrombin Time of HBsAg positive and HBsAg negative subjects are presented in Table 6 . The level of aspartate aminotransferase (AST) and alanine aminotransferase (ALT) of HBsAg positive subjects were significantly higher $(p<0.05)$ than that of HBsAg negative subjects, indicating liver injury. Also, elevated ALT (above ratio 1 of AST) observed in $\mathrm{HBSAg}$ positive subjects is an indication of viral hepatitis. A significant decline $(p<$ 0.05 ) in albumin level was observed in HBsAg positive subjects, indicating liver injury and corresponding decrease in protein synthesis by the liver (Whitby et al., 1988). The HBsAg positive subjects have significantly higher $(p<0.05)$ levels of total and direct bilirubin when compared to HBsAg negative subjects, these concur to the report of Rozen et al. (1970). Also observed is significant elevation $(p<0.05)$ of prothrombin time by more than 1.0 second above the upper reference limit, which is an indication of defect by hepatocytes to produce functional coagulation factors (Bonacini et al., 1997). Thus, indicating liver injury.

Table 2: Prevalence of HBsAg by Senatorial Zones of Kebbi State, Nigeria

\begin{tabular}{|c|c|c|c|}
\hline Senatorial Zone & No. of Screened subject & No. of $\mathrm{HBsAg}+\mathrm{ve}$ Subjects & Prevalence (\%) \\
\hline Kebbi Central & 125 & 17 & 13.6 \\
\hline Kebbi North & 126 & 19 & 15.1 \\
\hline Kebbi South & 110 & 24 & 21.8 \\
\hline
\end{tabular}

Table 3: Prevalence of HBsAg by Age Group in Kebbi State, Nigeria

\begin{tabular}{cccc}
\hline Age Group (Years) & No. of Screened Subjects & No. of HBsAg + ve Subjects & Prevalence (\%) \\
\hline $16-20$ & 68 & 7 & 10.3 \\
$21-25$ & 84 & 14 & 16.7 \\
$26-30$ & 110 & 23 & 20.9 \\
$31-35$ & 99 & 16 & 16.2 \\
\hline
\end{tabular}


Yakubu et al.: Prevalence of HBsAg Among Prospective Blood Donors and Pregnant Women in Kebbi State, Nigeria

Table 4: Prevalence of HBV Infection by Risk Factors among Male* Participants in Kebbi State

\begin{tabular}{|c|c|c|c|}
\hline Risk Factors & No. of Screened Subjects & $\begin{array}{l}\text { No. of HBsAg +ve } \\
\text { Subjects }\end{array}$ & $\begin{array}{c}\text { Prevalence } \\
\text { (\%) }\end{array}$ \\
\hline \multicolumn{4}{|l|}{ Marital Status } \\
\hline Single & 88 & 23 & 26.1 \\
\hline Married & 36 & 6 & 16.7 \\
\hline \multicolumn{4}{|l|}{ Occupation } \\
\hline State Government Employee & 42 & 6 & 14.3 \\
\hline Local Government Employee & 24 & 7 & 29.2 \\
\hline Self Employed & 58 & 16 & 27.6 \\
\hline Healthcare Worker & 0 & 0 & 0.0 \\
\hline \multicolumn{4}{|l|}{ History of Blood Transfusion } \\
\hline Yes & 0 & 0 & 0.0 \\
\hline No & 124 & 29 & 23.4 \\
\hline \multicolumn{4}{|l|}{ Cigarette Smoking } \\
\hline Yes & 3 & 0 & 0.0 \\
\hline No & 121 & 29 & 24.0 \\
\hline \multicolumn{4}{|l|}{ Alcohol Consumption } \\
\hline Yes & 0 & 0 & 0.0 \\
\hline No & 124 & 29 & 23.4 \\
\hline \multicolumn{4}{|c|}{ Previous Contact with HBV Infected Persons } \\
\hline Yes & 0 & 0 & 0.0 \\
\hline No & 124 & 29 & 23.4 \\
\hline \multicolumn{4}{|c|}{ History of Unprotected Casual Sex } \\
\hline Yes & 0 & 0 & 0.0 \\
\hline No & 124 & 29 & 23.4 \\
\hline \multicolumn{4}{|l|}{ Sharing of Sharp Objects } \\
\hline Yes & 36 & 29 & 80.6 \\
\hline No & 88 & 0 & 0.0 \\
\hline
\end{tabular}

${ }^{*}$ Total number of male participants= 124 
Table 5: Prevalence of HBV Infection by Risk Factors among Female* Participants in Kebbi State

\begin{tabular}{|c|c|c|c|}
\hline Risk Factors & $\begin{array}{c}\text { No. of Screened } \\
\text { Subjects }\end{array}$ & $\begin{array}{r}\text { No. of HBsAg } \\
\text { +ve Subjects }\end{array}$ & Prevalence (\%) \\
\hline \multicolumn{4}{|l|}{ Marriage Type } \\
\hline Monogamy & 91 & 8 & 8.8 \\
\hline Polygamy- $1^{\text {st }}$ Marriage & 90 & 7 & 7.8 \\
\hline Polygamy- $2^{\text {nd }}$ Marriage & 56 & 16 & 28.6 \\
\hline \multicolumn{4}{|l|}{ Occupation } \\
\hline State Government Employee & 19 & 2 & 10.5 \\
\hline Local Government Employee & 8 & 0 & 0.0 \\
\hline Not Employed & 205 & 27 & 13.2 \\
\hline Healthcare Worker & 5 & 2 & 40.0 \\
\hline \multicolumn{4}{|l|}{ History of Blood Transfusion } \\
\hline Yes & 87 & 3 & 3.5 \\
\hline No & 150 & 28 & 18.7 \\
\hline \multicolumn{4}{|l|}{ Cigarette Smoking } \\
\hline Yes & 0 & 0 & 0.0 \\
\hline No & 237 & 31 & 13.1 \\
\hline \multicolumn{4}{|l|}{ Alcohol Consumption } \\
\hline Yes & 0 & 0 & 0.0 \\
\hline No & 237 & 31 & 13.1 \\
\hline \multicolumn{4}{|c|}{ Previous Contact with HBV Infected } \\
\hline Persons & 0 & 0 & 0.0 \\
\hline Yes & 237 & 31 & 13.1 \\
\hline \multicolumn{4}{|l|}{ No } \\
\hline \multicolumn{4}{|c|}{ History of Unprotected Casual Sex } \\
\hline Yes & 0 & 0 & 0.0 \\
\hline No & 237 & 31 & 13.1 \\
\hline \multicolumn{4}{|l|}{ Sharing of Sharp Objects } \\
\hline Yes & 0 & 0 & 0.0 \\
\hline No & 237 & 31 & 13.1 \\
\hline
\end{tabular}

${ }^{\star}$ Total number of female participants $=237$

Table 6: Liver Function Parameters and Prothrombin Time of HBsAg Positive and HBsAg Negative Subjects

\begin{tabular}{|c|c|c|c|c|}
\hline \multirow[t]{2}{*}{ Parameters } & \multicolumn{2}{|c|}{ HBsAg Positive Subjects } & \multicolumn{2}{|c|}{ HBsAg Negative Subjects } \\
\hline & Male* & Female ${ }^{\star \star}$ & 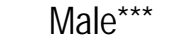 & Female ${ }^{\star \star \star \star}$ \\
\hline$\overline{\mathrm{AST}}(\mathrm{U} / \mathrm{L})$ & $24.28 \pm 6.04$ a & $21.26 \pm 4.50^{b}$ & $13.35 \pm 2.37^{c}$ & $12.36 \pm 1.68^{d}$ \\
\hline $\operatorname{ALT}(\mathrm{U} / \mathrm{L})$ & $31.00 \pm 10.70 \mathrm{a}$ & $30.01 \pm 8.30 \mathrm{a}$ & $9.04 \pm 1.48^{b}$ & $9.39 \pm 1.33^{b}$ \\
\hline Albumin (mg/dl) & $3.39 \pm 0.15^{a}$ & $3.40 \pm 0.23$ a & $4.57 \pm 0.39 b$ & $4.38 \pm 2.24^{b}$ \\
\hline Total Bilirubin (mg/dl) & $0.79 \pm 0.12^{a}$ & $0.74 \pm 0.07 a$ & $0.49 \pm 0.07^{b}$ & $0.54 \pm 0.07^{c}$ \\
\hline Direct Bilirubin (mg/dl) & $0.30 \pm 0.05^{a}$ & $0.29 \pm 0.04 \mathrm{a}$ & $0.17 \pm 0.03^{b}$ & $0.20 \pm 0.03 c$ \\
\hline Prothrombin Time (Seconds) & $16.1 \pm 0.90$ a & $16.4 \pm 1.10^{\mathrm{a}}$ & $11.6 \pm 0.80^{b}$ & $11.7 \pm 0.67^{b}$ \\
\hline
\end{tabular}

Values are expressed as Mean \pm Standard Deviation, Mean values with different superscripts in a row indicate significant difference $(p<0.05)$, AST $=$ Aspartate aminotransferase, ALT = Alanine aminotransferase, ${ }^{*}=29$ Subjects, ${ }^{* *}=31$ Subjects, ${ }^{* * *}=95$ Subjects, ${ }^{* * *}=206$ Subjects. 


\section{CONCLUSION}

The result of this study reveals that Kebbi State is HBV hyper-endemic, with males having higher prevalence than females. More so, subjects with history of sharing sharp objects and those with occupational exposure (healthcare workers) had high HBV prevalence. Therefore, there is need for continuous routine screening and rigorous awareness as well as vaccination of the populace so as to tackle the menace of HBV infection in Kebbi State.

\section{REFERENCES}

Adekeye, A.M., Chukwuedo, A.A., Zhakom, P.N. and Yakubu, R.S. (2013). Prevalence of Hepatitis B and $C$ among Blood Donors in Jos South LGA, Plateau State, Nigeria. Asian Journal of Medical Sciences, 5(5): 101-104.

Agarry, O.O. and Lekwot, G.Z. (2010). Prevalence of hepatitis $B$ virus and hepatitis $C$ virus in ante-natal patients in Gwagwalada- Abuja, Nigeria. Report and Opinion, 2(7): 48-50.

Alao, O.O., Okwori, E.E., Egwu C. and Audu, F. (2009). Seroprevalence of hepatitis B surface antigen among prospective blood donors in an urban area in Benue State. International Journal of Hematology, 5(2): 12.

Angyo, A.I., Okuonghea, H.O., Szlachetka, R. and Yakubu, A.M. (1995). Hepatitis B Surface Antigenaemia in Jos. Nigerian Journal of Paediatric, 22(2): 42-46.

Bello, H.S., Isa, M.A., Shettima, A. and Allamin, I.A. (2013). Prevalence of serological markers for acute hepatitis B virus among patients attending Sokoto specialist hospital, Sokoto, Nigeria. Journal of Microbiology and Biotechnology Research, 3(3): 132-135.

Bonacini, M., Hadi, G., Govindarajan, S. and Lindsay, K.L. (1997). Utility of a discriminate score for diagnosing advanced fibrosis or cirrhosis in patients with chronic hepatitis C infection. American Journal of Gastroenterology, 92: 1302-1304.

Doumas, B.T., Perry, B.W., Sasse, E.A. and Straumfjord, J.V. (1973). Standardization in bilirubin assays: evaluation of selected methods and stability of bilirubin solutions. Clinical Chemistry, 19(9): 984-93.

Doumas, B.T., Watson, W.A. and Biggs, H.G. (1971). Albumin standards and the measurement of serum albumin with bromcresol green. Clinical Chemistry Acta, 31(1): 87-96

Drosten, C., Nippraschk, T., Manegold, C., Meisel, H., Brixner, V., Roth, W.K., Apedjinou, A. and Günther,
S. (2004). Prevalence of hepatitis $B$ virus DNA in anti-HBc positive/HBsAg negative sera correlates with HCV but not HIV sero-status. Journal of Clinical Virology, 29: 59-68.

Eke, A.C., Eke, U.A., Okafor, C.I., Ezebielu, I.U. and Ogbuagu, C. (2011). Prevalence correlates and pattern of hepatitis B surface antigen in a low resource setting. Virology Journal, 8: 12.

Elgouhari, H.M., Tamimi, T.I.A.R. and Corey, W.D. (2008). Hepatitis B virus infection: Understanding its epidemiology, cause and diagnosis. Cleveland Journal of Medicine, 75: 881-889.

Forbi, J.C., Onyemauwa, N., Gyar, S.D., Oyeleye, A.O., Entonu, P. and Agwale, S.M. (2008). High prevalence of hepatitis $B$ virus among female sex workers in Nigeria. Revista do Instituto de Medicina Tropical de São Paulo, 50(4): 219-221.

Gitlin, N. (1997). Hepatitis B: diagnosis, prevention and treatment. Clinical Chemistry, 43: 1500-1506.

Harry, T.O., Bajani, M.D., Moses, A.E. (1994). Hepatitis $B$ virus infection among blood donors and pregnant women in Maiduguri, Nigeria. East Africa Medical Journal, 7(9): 595-597.

Heathcote, E.J. (2008). Demography and presentation of chronic hepatitis B virus infection. American Journal of Medicine, 121(12): S3-11.

Hollinger, F.B. and Liang, T.J. (2001). Hepatitis B Virus. In: Knipe DM et al eds. Fields Virology, $4^{\text {th }}$ ed. Philadelphia, Lippincott Williams \& Wilkins, 29713036.

Khan, F., Shams, S., Qureshi, I.D., Israr, M., Khan, H., Sarwar, M.T. and llyas, M. (2011). Hepatitis B virus infection among different sex and age groups in Pakistani Punjab. Virology Journal, 8: 225-235.

Lavanchy, D. (2004). Hepatitis B virus epidemiology, disease burden, treatment, and current and emerging prevention and control measures. Journal of Viral Hepatitis, 11(2): 97-107.

Liu, Z. and Hou, J. (2006). Hepatitis B virus (HBV) and Hepatitis $\mathrm{C}$ virus (HCV) dual infection. International. Journal of Medical Science, 3: 57-62.

Lule, G.N. (1997). Hepatitis: An update gastroenterology. African Health, 11:1-11.

Majori, S., Baldo, V., Tommasi, I., Malizia, M., Floreani, A., Monteiro, G., Ferrari, A., Accordini, A., Guzzo, P. and Baldovin, T. (2008). Hepatitis A, B and C infection in a community of sub-Saharan immigrants living in Verona (Italy). Journal of Travel Medicine. 15(5): 323-337.

Okoye, I.C. and Samba, S.A. (2006). Sero-epidemic survey of hepatitis $B$ in a population of Northern 
Nigeria. Animal Research International, 3(2): 485 488.

Oladele, O.O., Adesina. T.B., Omolola. Z.T. and Sunday. T.S. (2013). Prevalence of HBsAg and HIV among blood donors in Osogbo, Osun State, Nigeria. International Research Journal of Medicine and Medical Sciences, 1(3): 68-71.

Ilokoba, A.B., Salawu, F.K., Danburam, A., Olokoba, L.B., Midala, J.K., Badung, L.H. and Olatinwo, A.W.O. (2011). Hepatitis B virus infection among pregnant women in North-Eastern Nigeria- Acall for action. Nigerian Journal of Clinical Practice, 14(1): 10-13.

Olubuyide, I.O., Ola, S.O., Aliyu, B., Dosumu, O.O. and Arotiba, J.T. (1997). Hepatitis B and C in Doctors in Nigeria. Quarterly Journal of Medicine, 90: 417-422.

Pungpapong, S., Kim, W.R. and Poterucha, J.J. (2007). Natural History of Hepatitis B Virus Infection: An Update for Clinicians. Mayo Clinical Procedures, 82: 967-975.

Quick, A.J. (1935). Prothrombin time in haemophilia and in obstructive jaundice. Journal of Biological Chemistry 109: 73-74.

Reitman, S. and Frankel, S. (1957). A colorimetric method for the determination of serum glutamic oxalacetic and glutamic pyruvic transaminases. American Journal of Clinical Pathology, 28(1): 5663.

Rozen, P., Korn, R.J. and Zimmerman, H.J. (1970). Computer analysis of liver function tests and their interrelationship in 347 cases of viral hepatitis. Israel Journal of Science, 6: 67-79.

Ryan, K.J. and Ray, C.G. (2004). Sherris Medical Microbiology, 4th ed., McGraw Hill. ISBN 0838585299
Samuel, D., Muller, R. and Alexande, G. (2004). Educational Research, National Hepatitis B Virus Programme. Infectious Diseases, 234: 221-332.

Seeger, C. and Mason, W.S. (2000). Hepatitis B virus biology. Microbiology and Molecular Biology Review, 64(1): 51-68.

Sharma, S.K., Saini, N. and Chwla, Y. (2005). Hepatitis B Virus: Inactive carriers. Virology Journal, 2: 82.

Tietz, N.W., Rinker, A.D. and Shaw, L.M. (1983). International Federation of Clinical Chemistry. IFCC methods for the measurement of catalytic concentration of enzymes. Part 5.IFCC method for alkaline phosphatase (orthophosphoric-monoester phosphohydrolase, alkaline optimum, EC 3.1.3.1). Journal of Clinical Chemistry and Clinical Biochemistry, 21: 731-48.

Weichselbaum, T.E. (1946). Biuret method of serum total protein estimation. American Journal of Clinical Pathology, 16(1): 40.

Whitby, L.G., Smith, A.F. and Beckett, G.J. (1988). Lecture notes on clinical chemistry. Blackwell Scientific Publications, Oxford, UK, Pp: 476.

World Health Organization (WHO) (1998). Hepatitis B Immunization, WHO Position- Weekly Epidemiological Record, 73: 329-330.

Yakasai, I.A., Ayyuba, R., Abubakar, I.S. and Ibrahim, S.A. (2012). Sero-prevalence of hepatitis B virus infection and its risk factors among pregnant women attending antenatal clinic at Aminu Kano Teaching Hospital, Kano, Nigeria. Journal of Basic and Clinical Reproductive Sciences, 1: 49-55

Ziraba, A.K., Bwogi, J., Namale, A., Wainaina, C.W. and Mayanja-Kizza, H. (2010). Seroprevalence and risk factors for hepatitis virus infections among healthcare workers in a tertiary hospital in Uganda. BMC Infectious Diseases, 10: 191. 